WSRC-TR-2002-00568

Revision 0

\title{
Feasibility of Uranium Concentration Measurements For H Canyon Tank 16.7
}

\author{
R.J. Lascola and G.A. Cooper
}

\section{UNCLASSIFIED}

December 13, 2002

Westinghouse Savannah River Company Savannah River Site

Aiken, SC 29808 
WSRC-TR-2002-00568

Revision 0

Keywords: Uranium, Spectroscopy, Process Analysis

Classification: $\mathrm{U}$ P.E. Filpus-Luyckx, ADS/SRTC Authorized Derivative Classifier

Key References: NMMD Technical Task Request 2002-103

\title{
Feasibility of Uranium Concentration Measurements for H Canyon Tank 16.7
}

\author{
R.J. Lascola and G.A. Cooper
}

Publication Date: December 13, 2002

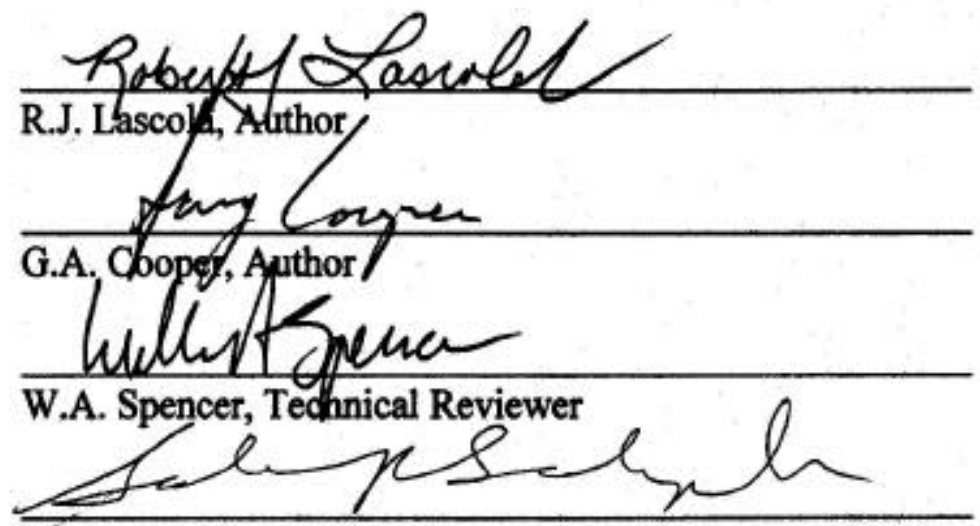

S.R. Salaymeh, Manager, S\&ATG-ADS, SRTC

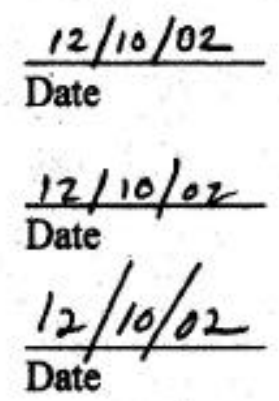

$12 / 11102$

Date

Westinghouse Savannah River Company

Savannah River Site

Aiken, SC 29808 
This document was prepared in conjunction with work accomplished under Contract No. DE-AC09-96SR18500 with the U. S. Department of Energy.

\section{DISCLAIMER}

This report was prepared as an account of work sponsored by an agency of the United States Government. Neither the United States Government nor any agency thereof, nor any of their employees, makes any warranty, express or implied, or assumes any legal liability or responsibility for the accuracy, completeness, or usefulness of any information, apparatus, product or process disclosed, or represents that its use would not infringe privately owned rights. Reference herein to any specific commercial product, process or service by trade name, trademark, manufacturer, or otherwise does not necessarily constitute or imply its endorsement, recommendation, or favoring by the United States Government or any agency thereof. The views and opinions of authors expressed herein do not necessarily state or reflect those of the United States Government or any agency thereof.

This report has been reproduced directly from the best available copy.

Available for sale to the public, in paper, from: U.S. Department of Commerce, National Technical Information Service, 5285 Port Royal Road, Springfield, VA 22161, phone: (800) 553-6847, fax: (703) 605-6900

email: orders@ntis.fedworld.gov

online ordering: http://www.ntis.gov/help/index.asp

Available electronically at http://www.osti.gov/bridge

Available for a processing fee to U.S. Department of Energy and its contractors, in paper, from: U.S. Department of Energy, Office of Scientific and Technical Information, P.O. Box 62, Oak Ridge, TN 37831-0062,

phone: (865)576-8401,

fax: (865)576-5728

email: $\underline{\text { reports@ adonis.osti.gov }}$ 
WSRC-TR-2002-00568 iv

\begin{abstract}
SRTC evaluated the feasibility of using the $H$ Canyon on-line diode array spectrophotometer to measure uranium concentrations in Tank 16.7. On-line measurements will allow an increase in highly enriched uranium (HEU) production by removing delays associated with off-line measurements. The instrument must be able to measure uranium at concentrations below $1.0 \mathrm{~g} / \mathrm{L}$ with an uncertainty no greater than 0.3 $\mathrm{g} / \mathrm{L}$. SRTC determined that the system has a limit of quantitation of $0.15 \mathrm{~g} / \mathrm{L}$. At concentrations of 0.5 and $1.0 \mathrm{~g} / \mathrm{L}$, the spectrometer uncertainty is $0.10 \mathrm{~g} / \mathrm{L}$. No design changes, such as an increase in flow cell pathlength, are required to obtain this performance. Expected levels of iron in Tank 16.7 solutions will not interfere with the measurement. The CHEMCHEK method should not be used for confirmatory analysis, as it contributes excessively to the overall uncertainty of the measurement. SRTC expects that the spectrophotometer will meet the measurement requirements for Tank 16.7 .
\end{abstract}




\section{TABLE OF CONTENTS}

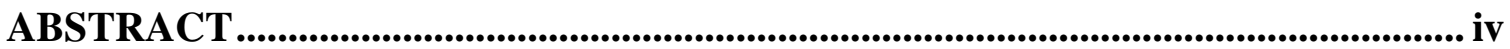

TABLE OF CONTENTS......................................................................................................... v

LIST OF FIGURES ..................................................................................................................... vi

LIST OF TABLES

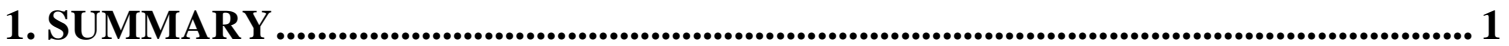

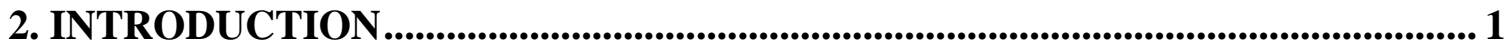

2.1 Scope ................................................................................................................................ 1

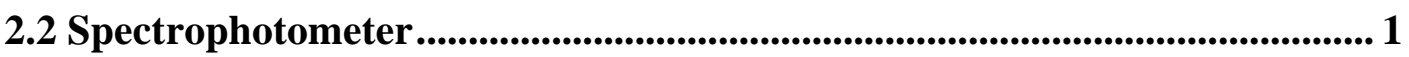

2.3 Study .............................................................................................................................. 3

3. EXPERIMENTAL METHODS........................................................................... 3

3.1 Uranium prediction models ...................................................................................... 3

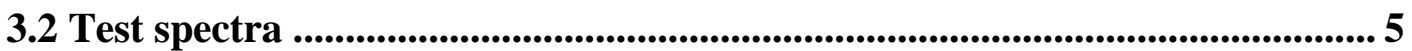

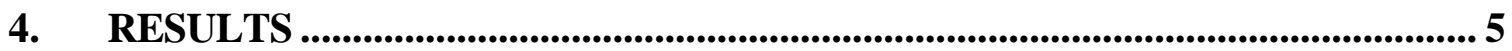

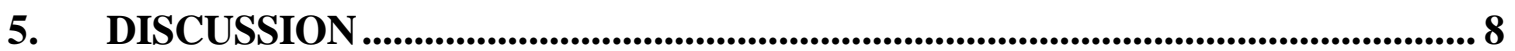

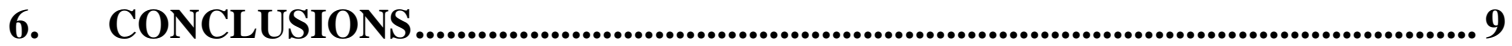

7. ACKNOWLDGEMENTS ........................................................................................ 10

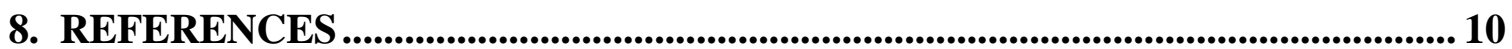




\section{LIST OF FIGURES}

Figure 1. Schematic diagram of spectrophotometer system. ......................................2

Figure 2. Spectra of low uranium solutions.......................................................................6

Figure 3. Spectra of iron-bearing solutions................................................................7

Figure 4. Spectra of low uranium solutions in H Canyon. ..............................................8

Figure 5. Uranium model uncertainty as a function of concentration. ......................10

\section{LIST OF TABLES}

Table 1. SRTC and H Canyon uranium prediction models.........................................5

Table 2. Prediction of low uranium solutions...................................................................66

Table 3. Measurements of low uranium calibration solutions in $\mathrm{H}$ Canyon...............8

Table 4. Estimated spectrometer uncertainties..............................................................10 


\section{SUMMARY}

This report summarizes work performed to determine the feasibility of using the $\mathrm{H}$ Canyon on-line diode array spectrophotometer to measure uranium concentrations in Tank 16.7. On-line measurements will allow an increase in highly enriched uranium (HEU) production by removing delays associated with off-line measurements. The instrument must be able to measure uranium at concentrations below $1.0 \mathrm{~g} / \mathrm{L}$ with an uncertainty no greater than $0.3 \mathrm{~g} / \mathrm{L}$. SRTC determined that the system has a limit of quantitation of $0.15 \mathrm{~g} / \mathrm{L}$. At concentrations of 0.5 and $1.0 \mathrm{~g} / \mathrm{L}$, the spectrometer uncertainty is $0.10 \mathrm{~g} / \mathrm{L}$. No design changes, such as an increase in flow cell pathlength, are required to obtain this performance. Expected levels of iron in Tank 16.7 solutions will not interfere with the measurement. The CHEMCHEK method should not be used for confirmatory analysis, as it contributes excessively to the overall uncertainty of the measurement. SRTC expects that the spectrophotometer will meet the measurement requirements for Tank 16.7.

\section{INTRODUCTION}

\subsection{Scope}

The scope of the work described in this report is defined in the Nuclear Materials Management Division (NMMD) Technical Task Request 2002-103, "Demonstrate Spectrophotometer on 1DW Stream to LLW". The spectrophotometer to which the Technical Task Request refers is one of two UV-visible spectrophotometers installed in $\mathrm{H}$ Canyon which are being used to monitor uranium and nitrate concentrations in nine tanks in the First and Second Uranium Cycles. NMMD would like to extend the system to include measurements of uranium in Tank 16.7. On-line measurements will increase HEU processing rates by removing delays associated with off-line analysis. Tank 16.7 receives the 1DW stream before it is sent to Low Activity Waste. NMMD desires a detection limit less than $1.0 \mathrm{~g} / \mathrm{L} \mathrm{U}$, with an uncertainty ${ }^{*}$ of less than $0.3 \mathrm{~g} / \mathrm{L} \mathrm{U}$. No acid or nitrate measurements are required for this stream. Uranium measurements at Tank 16.7 may be hampered by iron, which is present at concentrations up to $1 \mathrm{~g} / \mathrm{L}$.

\subsection{Spectrophotometer}

The spectrophotometers currently installed in H Canyon have been described in an earlier document. ${ }^{1}$ Their operational principle can be described as follows, with reference to the schematic diagram shown in Figure 1. Using an optical multiplexer and fiber optics, white light is selectively directed to one of several measurement points, where it is partially absorbed in a flow cell by solution which has been sampled from a processing tank. The transmitted light is directed to a spectrometer, where it is diffracted and focused on a diode array detector. The resulting spectrum is interpreted by a computer, which

\footnotetext{
* Throughout this report, the uncertainty is defined as twice the standard deviation, $\sigma$, of a series of measurements. For a chemometric model, the uncertainty is twice the standard prediction error.
} 


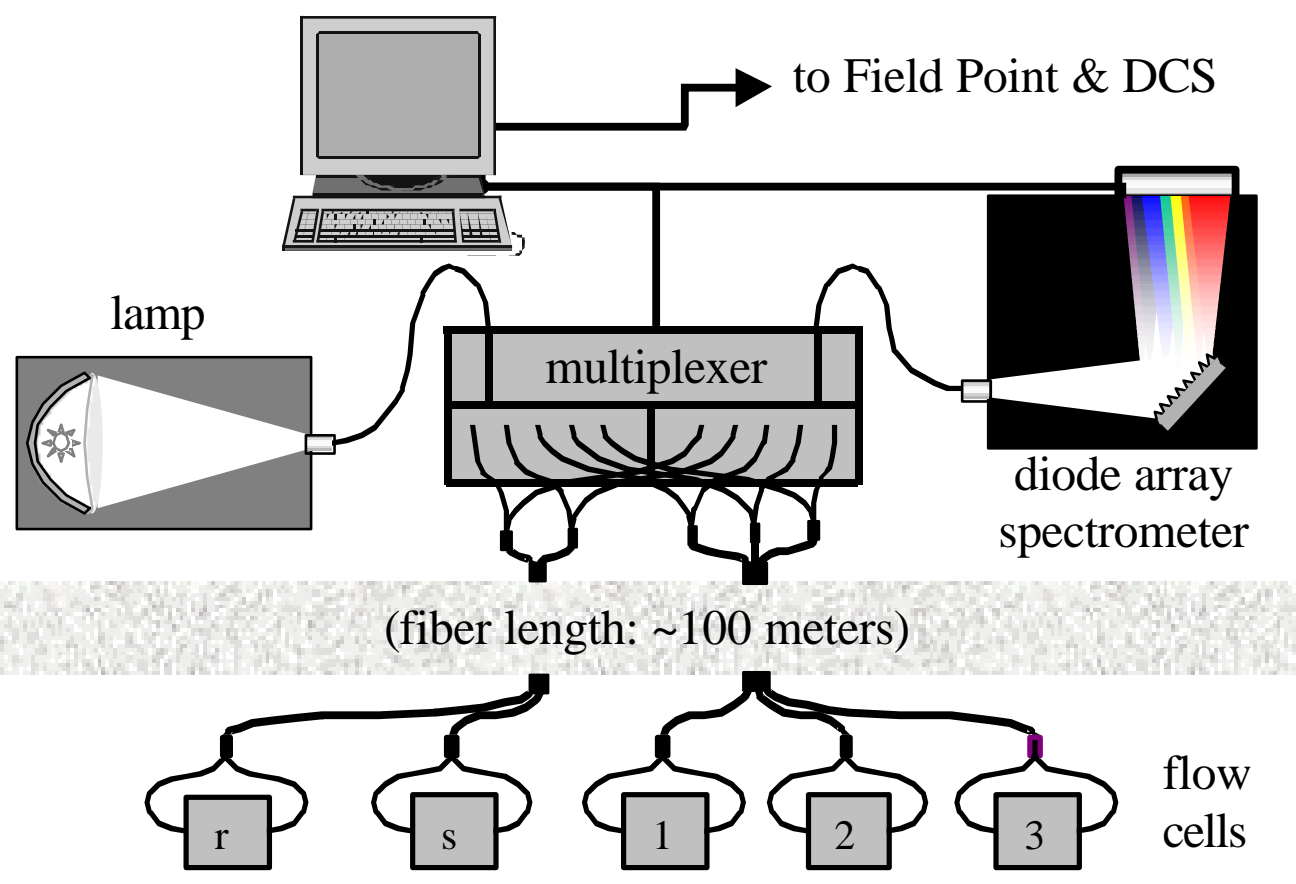

Figure 1. Schematic diagram of spectrophotometer system.

uses a chemometric model to correlate a uranium or nitrate concentration to the spectrum. The computer then communicates the result of the analysis to the control room digital control system (DCS).

The relationship between light absorbance and analyte concentration is described by Beer's Law, ${ }^{2}$

$$
A(\lambda)=\Sigma_{i} \varepsilon_{i}(\lambda) b c_{i}
$$

where $A$ is the total light absorption (a dimensionless quantity), $\lambda$ is the wavelength of light, $\boldsymbol{\varepsilon}_{i}(\lambda)$ is the wavelength-dependent extinction coefficient of species $i, b$ is the optical pathlength, and $c_{i}$ is the concentration. The summation includes all chemical species that are present in the solution. The inverse relationship between pathlength and concentration means that the same absorbance (i.e. analytical signal) will be observed for two solutions with different analyte concentrations if a proportionally longer pathlength is used to measure the less concentrated solution.

The extinction coefficient, $\boldsymbol{\varepsilon}$, for a chemical species may change as solution conditions such as temperature or acidity change. Other chemical species may also absorb light at the same wavelengths as the analyte of interest. For these reasons, it is not always possible to use Beer's Law to predict analyte concentrations. The $\mathrm{H}$ Canyon spectrometer uses chemometric prediction models ${ }^{3}$ to reduce or eliminate the effects of chemical interferents and solution conditions. These models are described in Reference 1. The models are designed to be sensitive to variations in the absorbance spectra that 
correlate with changes in analyte concentration. Variations due to changing solution conditions or interfering species are ignored.

Uranium measurement models for the $\mathrm{H}$ Canyon spectrophotometers are defined for conditions of 0-11 g/L U, 0.05-8 M nitrate, $<1 \mathrm{~g} / \mathrm{L}$ mercury, $<3 \mathrm{~g} / \mathrm{L}$ iron $(\mathrm{Fe})$, and a temperature range (at the flow cell) of $20-50{ }^{\circ} \mathrm{C}$. Tank 16.7 would be monitored with the spectrophotometer labeled "Unit 2". The uncertainty of the uranium measurement for Unit 2 is $0.4 \mathrm{~g} / \mathrm{L} \mathrm{U}$. This value, which is used for flowsheet calculations, includes all sources of uncertainty, including those associated with the confirmatory analytical method. ${ }^{*}$ The uncertainty associated with the instrument itself increases with an increase of concentration, and ranges from 0.1 to $0.3 \mathrm{~g} / \mathrm{L} \mathrm{U}$.

\subsection{Study}

The expected concentrations for the 1DW stream are $<1 \mathrm{~g} / \mathrm{L} \mathrm{U}$, approximately $4 \mathrm{M}$ nitric acid, $<1 \mathrm{~g} / \mathrm{L} \mathrm{Fe}^{3+},<1 \mathrm{~g} / \mathrm{L}$ sulfur, and ambient temperature. Sulfur is not expected to contribute to the spectroscopy of the solutions, and the concentrations of the other species are within the ranges for which the existing prediction models are defined. Therefore, the desired measurement should be feasible.

SRTC conducted several studies to confirm this ssessment and define the expected performance of the instrument. The limits of detection and quantitation were determined. The existing uranium measurement models were developed primarily for applications where uranium concentrations were greater than approximately $2 \mathrm{~g} / \mathrm{L}$. Little validation data were obtained for the lower uranium concentrations relevant to this application. The measurement uncertainty at the lower concentrations was calculated. Prior work indicated that the uncertainty varies with concentration; however, only the most conservative value, associated with high concentrations, is used for flow sheet calculation. This value is not relevant for measurements at the lower concentrations. Finally, an appropriate optical pathlength was chosen, based on the expected absorbances of both the uranium and interfering species such as $\mathrm{Fe}^{3+}$.

\section{EXPERIMENTAL METHODS}

The majority of the data reported here was generated at SRTC. Some data was obtained from calibration activities for the spectrophotometers after their installation in H Canyon.

\subsection{Uranium prediction models}

All chemometric prediction models are specific to the spectrometer with which the calibration data were generated. As the spectrometer used for the studies performed in SRTC is not the same as the H Canyon spectrometer which will be used to make the

\footnotetext{
* The confirmatory analytical method for the tanks currently monitored by "Unit 2" is UV-visible diode array spectroscopy performed at CLAB.
} 
process measurements, the performance of the models associated with each spectrometer must be demonstrated to be equivalent. A comparison of the basic components of each calibration - standard solutions, equipment, and software - shows that results obtained with the SRTC instrument are expected to be representative of those that would be obtained in H Canyon.

Both the SRTC and H Canyon models were calculated using spectra obtained from the same set of standard solutions. The composition of those solutions are described in Reference 1. The solutions were made gravimetrically from stock solutions of uranium, nitric acid, and water. The stock solution concentrations were determined by Analytical Development Section standard analytical techniques, as follows: uranium was measured by ICP-MS and nitric acid was measured by titration. Solution masses were measured with balances calibrated under the SRTC Measurement \& Test Equipment program and/or the ADS Measurement Systems \& Equipment program. Densities were measured with densitometers (DMA 35N, Anton Paar USA, Ashland, VA) that were validated by comparison with water before and after the measurements.

The components of the SRTC spectrophotometer were functionally identical to those in the $\mathrm{H}$ Canyon instrument. The two data sets were acquired using the same light source, fiber optics, and cuvette. The difference in the data sets arose from the use of a different diode array spectrometer. However, as the same model spectrometer Zeiss MCS 501, 1024 pixels, sensitivity 180-1100 nm) was used in both instruments, the data sets are expected to be of similar quality.

The same computer and data acquisition program, zsfm.exe, was used to acquire the data with both spectrometers. This program was a subset of the Onlinez.exe program used to control the $\mathrm{H}$ Canyon spectrophotometers, and used identical core data acquisition routines. Data analysis for the SRTC spectrometer is performed in the Matlab 6.1 environment (Release 12, Mathworks, Inc., Natick, MA), using commercially available software (PLS_Toolbox 2.0, Eigenvector Research, Manson, WA). This software was also used for scoping studies for the $\mathrm{H}$ Canyon model development. The predictive ability of models generated with this software matched that of models generated with the ADS program mvasrs.exe, which are used in the H Canyon spectrometers.

The redundancy of the standard solutions, equipment, and analysis software used in the development of the SRTC and H Canyon models indicates that results obtained with the SRTC system will be reliable predictors of performance in H Canyon. This assertion is demonstrated by a comparison of prediction errors for the models associated with the two instruments, as shown in Table 1. The first set of numbers shows the ability of the models to reproduce the concentrations of the solutions in the original calibration set. The second set describes the predictive ability of the models for validation solutions that are not included in the calibration. The small differences between the models can be attributed to higher noise for the SRTC spectrometer. However, the predictive ability of the two models are similar, and results obtained with the SRTC spectrophotometer can be expected to hold true for the H Canyon instrument. 
Table 1. SRTC and H Canyon uranium prediction models.

\begin{tabular}{|c|c|c|}
\hline & SRTC & H Canyon (Unit 2) \\
\hline Name & Umodel_d_c3.PLS & HCURN21.PLS \\
\hline Calibration $\sigma(\mathrm{g} / \mathrm{L})$ & 0.11 & 0.07 \\
\hline Validation $\sigma(\mathrm{g} / \mathrm{L})$ & 0.16 & 0.11 \\
\hline
\end{tabular}

\subsection{Test spectra}

The original uranium calibration models were generated for tanks with expected concentrations greater than $2 \mathrm{~g} / \mathrm{L}$. Since concentrations less than $1 \mathrm{~g} / \mathrm{L}$ are expected at Tank 16.7, the suitability of the models for this measurement was determined by reexamining two aspects of the calibration data set. First, the lowest uranium concentration in the original calibration solution set was $0.5 \mathrm{~g} / \mathrm{L}$ (apart from blank solutions), providing a lower bound for the desired $1 \mathrm{~g} / \mathrm{L}$ detection threshold. However, we obtained little validation data at that concentration in the original spectrophotometer development work. Second, the calibration data was acquired using a $1 \mathrm{~cm}$ pathlength cuvette. The typical flow cell pathlength for the $\mathrm{H}$ Canyon spectrophotometer is approximately $2.54 \mathrm{~cm}(1 \mathrm{inch})$. The longer pathlength increases the sensitivity of the measurement but also increases the effect of interfering species such as Fe.

To test the model performance at low uranium concentrations and long pathlengths, new test solutions were required. Seven uranium-bearing solutions were generated using gravimetric techniques. A new uranium stock solution was made and analyzed by ADS standard methods (ICP-MS, $5.6 \mathrm{~g} / \mathrm{L}, \sigma=3.6 \%, 14$ replicates). All solutions were made to $4 \mathrm{M}$ nitric acid. The target uranium concentrations were $0.05,0.10,0.20,0.40,0.60$, 0.80 , and $1.0 \mathrm{~g} / \mathrm{L}$. Two test solutions were also made containing 0.2 and $1.0 \mathrm{~g} / \mathrm{L} \mathrm{Fe}$. These solutions were made volumetrically from a commercially available standard solution $\left(1000 \mu \mathrm{g} / \mathrm{mL} \mathrm{Fe}^{3+}\right.$, High Purity, Charleston, SC).

The equipment used to measure the spectra of the test solutions was identical to that used to obtain the calibration solutions, with the substitution of a $4 \mathrm{~cm}$ cuvette. This pathlength represents an intermediate value between the $2.54 \mathrm{~cm}$ pathlength which is the standard length for flow cells in $\mathrm{H}$ Canyon and $5.08 \mathrm{~cm}$ pathlength which can be achieved by incorporating a retroreflection design into the flow cell. The longer pathlength cell was considered as an alternative in the event that adequate uranium absorption could not be measured with the typical $2.54 \mathrm{~cm}$ flow cell.

\section{RESULTS}

Absorbance spectra of the seven uranium-bearing solutions plus water are shown in Figure 2a. The progression of the spectra with increasing uranium concentration is partially obscured by a shifting baseline. The effects of the shifting baseline can be removed by taking the second derivative of the spectra, which is part of the normal data 

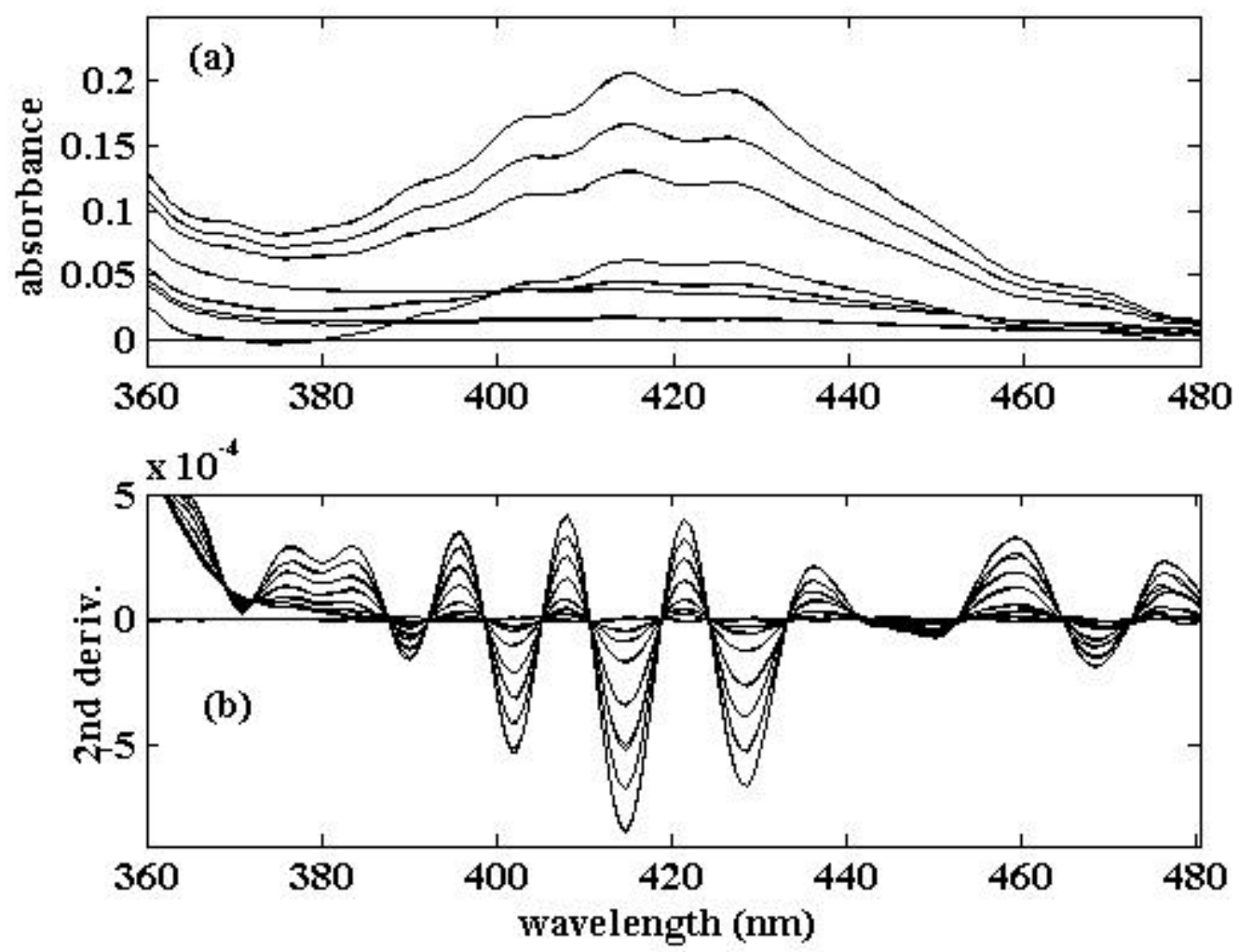

Figure 2. Spectra of low uranium solutions.

pretreatment associated with the uranium models. The results of this operation are shown in Figure 2b. Here, the dependence of the spectra on uranium concentration is readily apparent.

All seven uranium spectra are distinguishable from the blank spectrum. The quality of the data, even at the lowest concentrations, can also be seen from the results of using the SRTC model to predict the concentrations. As shown in Table 2, the actual and predicted concentrations agree for all solutions.

Table 2. Prediction of low uranium solutions.

\begin{tabular}{|c|c|c|}
\hline Solution & {$[\mathbf{U}]$ "true" $(\mathbf{g} / \mathbf{L})$} & {$[\mathbf{U}]_{\text {predicted }}(\mathbf{g} / \mathbf{L})$} \\
\hline 1 & 0.05 & 0.04 \\
\hline 2 & 0.10 & 0.11 \\
\hline 3 & 0.20 & 0.21 \\
\hline 4 & 0.40 & 0.45 \\
\hline 5 & 0.61 & 0.62 \\
\hline 6 & 0.81 & 0.85 \\
\hline 7 & 1.01 & 1.10 \\
\hline Blank & 0.00 & -0.01 \\
\hline
\end{tabular}


Absorption spectra of the two iron-bearing solutions and water are shown in Figure 3a. As with the uranium spectra, these spectra are confounded by baseline drifts that are removed by taking the second derivative, as shown in Figure 3b. Two aspects of the iron spectra require comment. First, despite their appearance at the same wavelengths as the uranium absorption, the peaks between $400-420 \mathrm{~nm}$ are not due to uranium. This is evident from the derivative spectra, which are different for iron and uranyl nitrate (shown in gray). Second, at the wavelength regions used in the uranium prediction model (380$460 \mathrm{~nm}$ ), the total light absorption with the $4 \mathrm{~cm}$ cell is low, even for the $1 \mathrm{~g} / \mathrm{L}$ iron solution. Both the 1 and 2 inch flow cells could be used without raising concerns about excess light absorption due to the iron.

Supplemental data from field calibrations of the Unit 2 spectrophotometer in $\mathrm{H}$ Canyon provided additional validation information. Figure $4 \mathrm{a}$ shows the absorbance spectra for a calibration solution of $0.96 \mathrm{~g} / \mathrm{L}$ uranium and $1.05 \mathrm{M}$ nitrate poured into the flow cells associated with Tanks 12.3 and 17.4. The spectra differ due to the different pathlength of the two flow cells $-2.54 \mathrm{~cm}$ for Tank 17.4, and $1.52 \mathrm{~cm}$ for Tank 12.3. Due to the linear relationship between absorbance, pathlength and concentration, the spectrum from Tank 12.3 corresponds to the absorbance of a $0.57 \mathrm{~g} / \mathrm{L}$ uranium solution in a $2.54 \mathrm{~cm}$ flow cell. In both cases the spectra are obtained with a good signal-to-noise ratio and are well above the baseline spectrum of water. The derivative spectrum shown in Figure $4 \mathrm{~b}$ shows similarly good signal-to-noise. Table 3 shows the predictions of several low-uranium solutions poured into various tanks monitored with Unit 2. In all cases, the predictions match the expected values within the uncertainty of the prediction model.

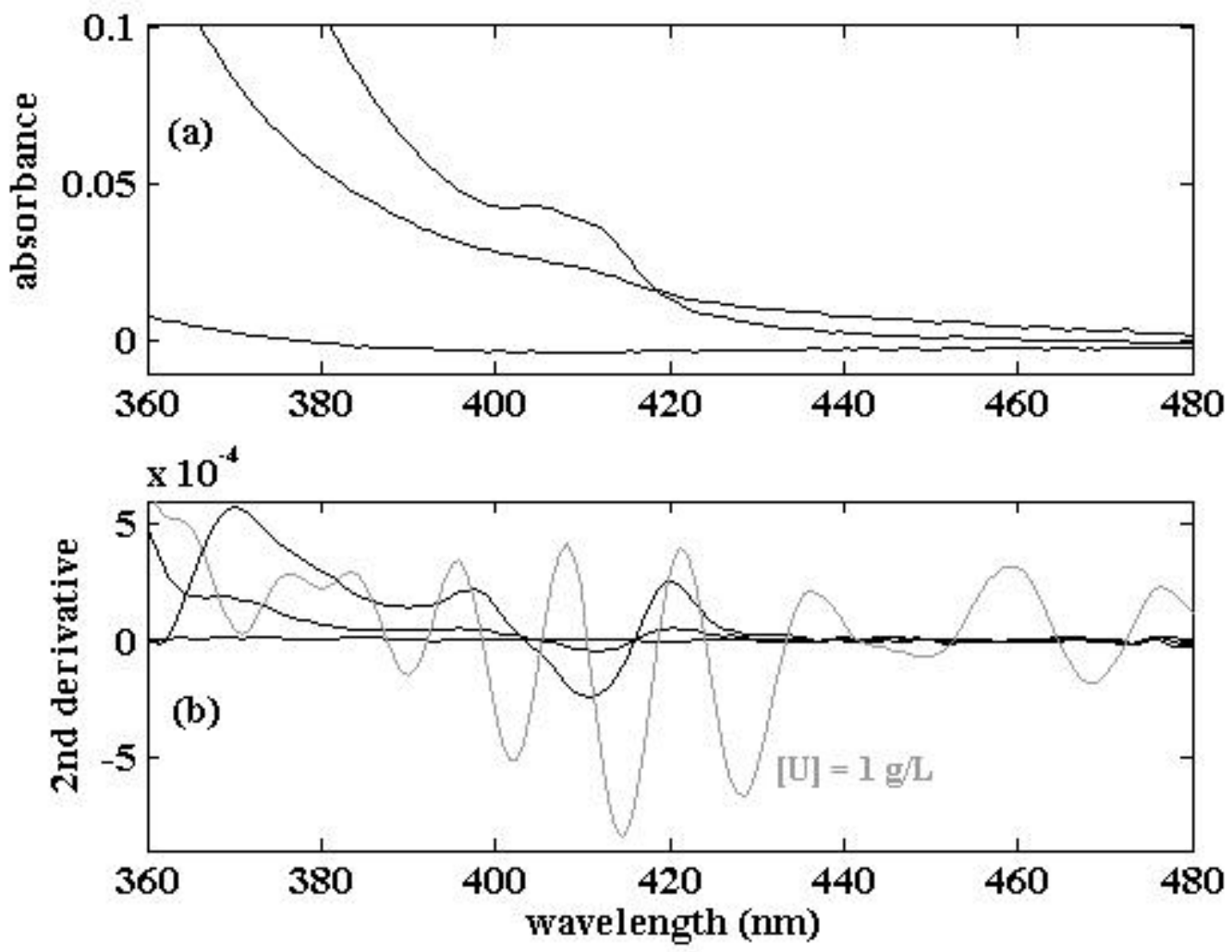

Figure 3. Spectra of iron-bearing solutions. 

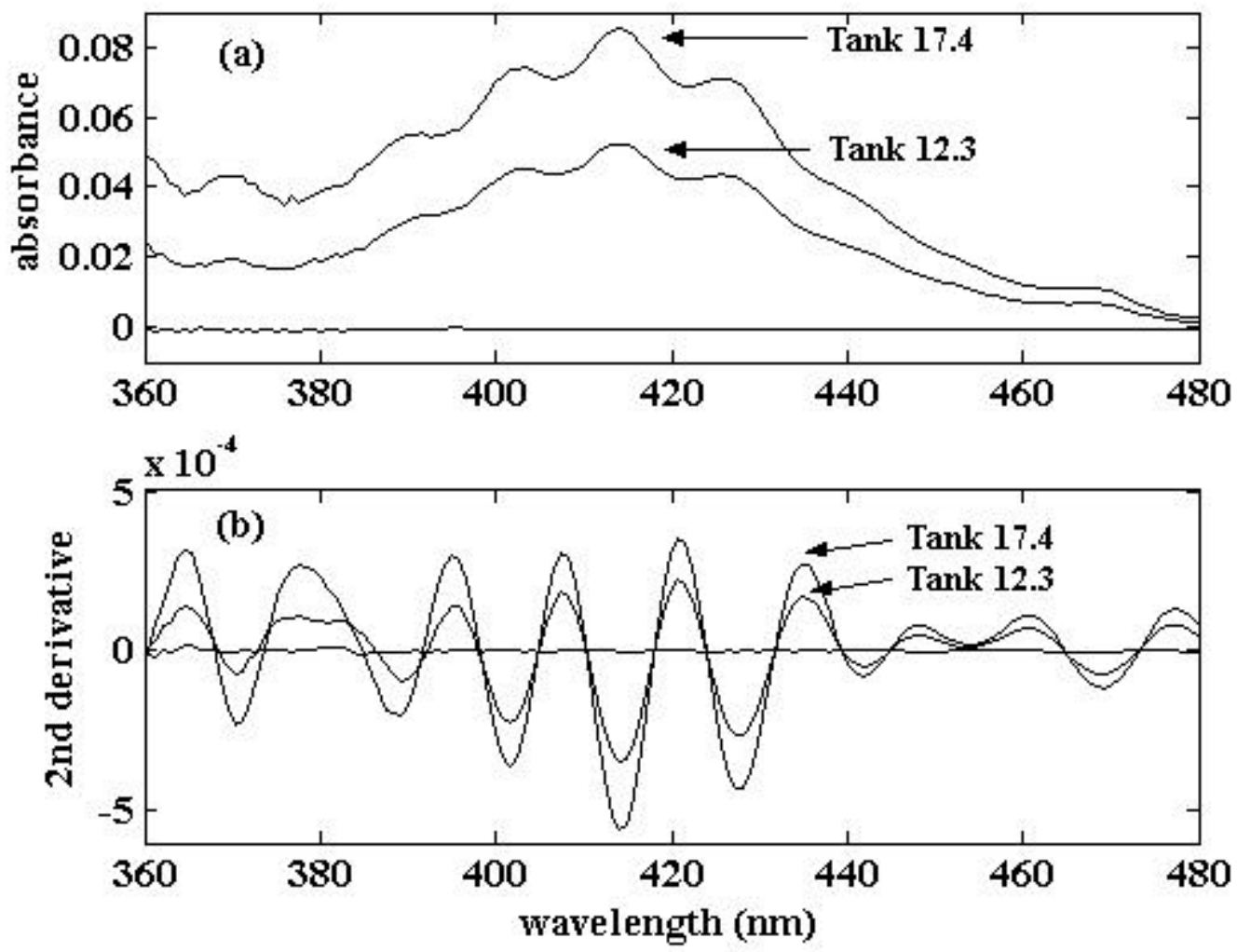

Figure 4. Spectra of low uranium solutions in H Canyon.

Table 3. Measurements of low uranium calibration solutions in $\mathbf{H}$ Canyon.

\begin{tabular}{|c|c|c|c|}
\hline Tank & Pathlength $(\mathbf{c m})$ & {$[\mathbf{U}]^{\prime}$ "rue" $(\mathbf{g} / \mathbf{L})$} & {$[\mathbf{U}]_{\text {predicted }}(\mathbf{g} / \mathbf{L})$} \\
\hline 12.3 & 1.52 & 0.96 & 0.91 \\
\hline 14.5 & 2.54 & 0.75 & 0.75 \\
\hline 17.4 & 2.54 & 0.96 & 0.92 \\
\hline 18.1 & 2.54 & 0.96 & 0.99 \\
\hline 18.7 & 2.54 & 0.75 & 0.78 \\
\hline
\end{tabular}

\section{DISCUSSION}

The above data indicates that a $2.54 \mathrm{~cm}$ pathlength flow cell design should be used for the 16.7 sampler. Both the SRTC and H Canyon data show that uranium concentrations well below $1 \mathrm{~g} / \mathrm{L}$ will be observed, and it is not necessary to incorporate a longer pathlength to improve sensitivity. The iron spectra show that the presence of iron will not obscure the uranium absorptions; thus there is no reason to go to a shorter pathlength. In addition, the $2.54 \mathrm{~cm}$ pathlength allows the same flow cell design for the 16.7 sampler as is currently being used on the majority of the tanks being monitored. 
There is no universally agreed-upon mathematical definition for the limit of detection (LOD) or limit of quantitation (LOQ) for an analytical method. However, the commonly used defintions are three and ten times the standard deviation of the measurement when the analyte concentration is zero. ${ }^{2}$ Estimates of the blank standard deviation are consistent for both the SRTC and H Canyon spectrometers. Analysis of 34 blanks at SRTC resulted in an average measurement of $0.001 \pm 0.015 \mathrm{~g} / \mathrm{L} \mathrm{U}$. Analysis of 34 blanks with the Unit 2 spectrophotometer (at several different tanks) resulted in an average measurement of $-0.005 \pm 0.010 \mathrm{~g} / \mathrm{L} \mathrm{U}$. The above definitions correspond, in the most conservative case, to a LOD of $0.04 \mathrm{~g} / \mathrm{L} \mathrm{U}$ and a LOQ of $0.15 \mathrm{~g} / \mathrm{L} \mathrm{U}$.

The limit of quantitation is consistent with the expected uncertainty of the measurement at low concentration. Figure 5 shows the uncertainty for uranium concentrations arising from the ability of the model to reproduce the standard concentrations. The results for three different uranium prediction models are shown, indicating the consistency of the results for different spectrometers. The rise at low concentrations comes from a decrease in the signal-to-noise ratio of the data. The resulting absolute errors, calculated from the uranium concentration and the percent error, are given in Table 4. Table 4 shows the total propagated error for the spectrophotometer, which includes contributions from the uncertainty of the uranium concentration in the standard solutions (1.5\%). Uncertainty from sampler operation is not included in this calculation, since the sampler will not be circulating during the measurement. The resulting uncertainty at $1 \mathrm{~g} / \mathrm{L}, 0.10 \mathrm{~g} / \mathrm{L}$, is consistent with the LOQ estimated above.

These uncertainty estimates do not include any contribution from the uncertainty associated with confirmatory analysis by CLAB. The combined propagated uncertainty is used for flow sheet calculations. The use of a relatively imprecise confirmatory method can increase the total uncertainty to a level that misrepresents the accuracy of the on-line method. For example, the typical method used to analyze samples from Tank 16.7 is CHEMCHEK (fluorescence), which has a precision of $15 \%$. Combining this result with the intrinsic spectrometer uncertainty yields a total uncertainty of $0.18 \mathrm{~g} / \mathrm{L}$ for $0.5 \mathrm{~g} / \mathrm{L} \mathrm{U}$, and $0.32 \mathrm{~g} / \mathrm{L}$ for $1 \mathrm{~g} / \mathrm{L} \mathrm{U}$. The latter value exceeds the requested uncertainty defined in the task request. However, the use of a more precise confirmatory measurement technique, such as diode array spectroscopy, Davies-Grey titration, or isotope dilution/mass spectroscopy, would improve the overall reported uncertainty. This calculation suggests that an alternate confirmatory method should be chosen for Tank 16.7 samples.

\section{CONCLUSIONS}

The $\mathrm{H}$ Canyon spectrophotometer can measure uranium concentrations at Tank 16.7 at the requested concentrations of $1.0 \mathrm{~g} / \mathrm{L}$, with an uncertainty of $0.3 \mathrm{~g} / \mathrm{L}$. The presence of iron at concentrations of at least $1 \mathrm{~g} / \mathrm{L}$ will not adversely affect the uranium measurements. The typical flow cell design, with a pathlength of $2.54 \mathrm{~cm}$, can be used for this application. The limit of quantitiation is $0.15 \mathrm{~g} / \mathrm{L} \mathrm{U}$. The uncertainty of the method is estimated to be $0.10 \mathrm{~g} / \mathrm{L}$ for solutions containing either 0.5 or $1.0 \mathrm{~g} / \mathrm{L} \mathrm{U}$. For 


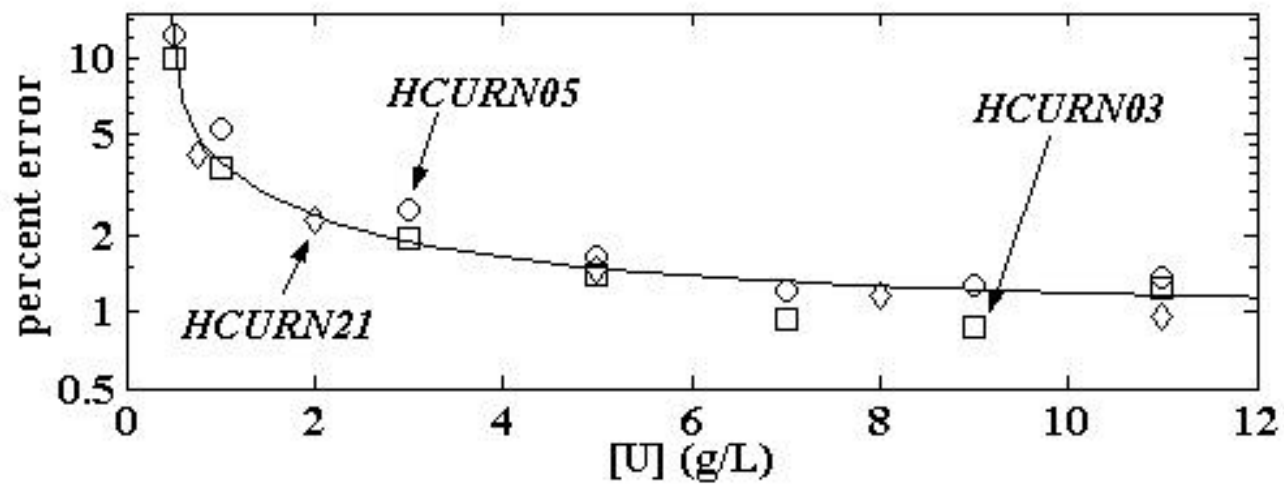

Figure 5. Uranium model uncertainty as a function of concentration.

Table 4. Estimated spectrometer uncertainties.

\begin{tabular}{|c|c|c|c|c|}
\hline$[\mathbf{U}](\mathbf{g} / \mathbf{L})$ & \% error, prediction & $\boldsymbol{\sigma}_{\text {model }}(\mathbf{g} / \mathbf{L})$ & $\boldsymbol{\sigma}_{\text {spec }}(\mathbf{g} / \mathbf{L})^{\mathbf{a}}$ & $\boldsymbol{\sigma}_{\text {total }}(\mathbf{g} / \mathbf{L})^{\mathbf{b}}$ \\
\hline 0.50 & 10 & 0.05 & 0.051 & 0.091 \\
\hline 1.0 & 5 & 0.05 & 0.052 & 0.16 \\
\hline 2.0 & 2.5 & 0.05 & 0.058 & 0.31 \\
\hline
\end{tabular}

b - Based on CHEMCHEK confirmatory analysis: $\sigma_{\text {total }}^{2}=\sigma_{\text {spec }}^{2}+\sigma_{\text {CLAB }}^{2}\left(\sigma_{\text {CLAB }}^{2}=0.15 \times[U]\right)$.

the purposes of flowsheet calculations, the uncertainty of the confirmatory method must be included. The uncertainty associated with the CHEMCHEK method, which is often used to analyze solutions from Tank 16.7, is too large for that technique to be used as the confirmatory method.

\section{ACKNOWLDGEMENTS}

The authors thank J.C. Black for experimental assistance and Dr. F.M. Pennebaker for the iron standard.

\section{REFERENCES}

1) R.J. Lascola, R.R. Livingston, M.A. Sanders, J.E. McCarty, and G.A. Cooper, "On Line Spectrophotometric Measurements of Uranium and Nitrate in H Canyon", Report WSRC-TR-2002-00334, Savannah River Technology Center, Aiken, SC (2002).

2) D.A. Skoog and J.J. Leary, Principles of Instrumental Analysis, $4^{\text {th }}$ Ed., Saunders College Publishing, Orlando, FL (1992).

3) K.S. Booksh, "Chemometric Models in Process Analysis", in Encyclopedia of Analytical Chemistry, R.A. Myers, Ed., p, 8145-8169, John Wiley \& Sons, Chichester (2000). 